\title{
AN EXHAUSTIVE REVIEW ON EMERGING DRUG TARGETS OF TUBERCULOSIS WITH SPECIAL EMPHASIS ON CELL WALL SYNTHESIS
}

\author{
SNEHAL R THAKAR, DEEPALI A BANSODE*
}

Department of Pharmaceutical Chemistry, Poona College of Pharmacy, Bharati Vidyapeeth (Deemed to be University), Pune, Maharashtra, India. E mail: deepali_mhaske@rediffmail.com

Received: 7 May 2021, Revised and Accepted: 24 July 2021

\section{ABSTRACT}

Tuberculosis (TB) is one of the top 10 causes of mortality and morbidity. Worldwide, yet, it has been over 60 years since a novel drug was introduced in market to treat the disease exclusively. Increased number of drug resistant TB cases has prompted the search for novel potent anti-TB drug. Mycobacterial cell wall has unique structure which provides integrity to the cell. The future development of new potent anti-TB drug targets is associated with the synthesis of various cell wall constituents; the structural and genetic information about mycobacterial cell wall envelope is now available. In the present review, we have focused on prospective drug targets that can be optimum triumph for successful drug candidate.

Keywords: Cell wall synthesis, Enzymatic pathways, Mycolic acid, Tuberculosis.

(C) 2021 The Authors. Published by Innovare Academic Sciences Pvt Ltd. This is an open access article under the CC BY license (http://creativecommons.org/ licenses/by/4.0/) DOI: http://dx.doi.org/10.22159/ijls.2021v9i5.42000. Journal homepage: https://innovareacademics.in/journals/index.php/ijls

\section{INTRODUCTION}

Tuberculosis (TB), the infection caused by Mycobacterium species, is the major disease across the globe. There are three species of mycobacteria which are prominently observed in major population of patients. The species are Mycobacterium tuberculosis (Mtb), Mycobacterium avium, and Mycobacterium smegmatis out of which Mtb infection is more common. TB is one of the top 10 causes of death worldwide. According to recent World Health Organization's report, over 10 million people get infected with TB. Despite widespread use of BCG vaccine, TB infection has not been reduced as compared to other diseases [1]

The disease has reemerged as growing global health problem not only because of lack of proper therapeutic agents but also due to the development of drug resistance by mycobacterial strains. The emergence of multidrug-resistant (MDR) and extremely drug resistance (XDR) strains of this lethal pathogen renders current treatment strategies very difficult, and in some cases, there is complete failure [2]. Thus, the development of new anti-TB drug is an urgent need. The unrevealing of mycobacterial cell wall envelope has given new key to successful development of anti-TB drugs. The review describes about overview of current treatment its drawback and future prospective of drug development against TB infection.

\section{CATEGORIES OF TB INFECTIONS}

There are four categories of TB infection. Primary infection Category I belongs to new cases of sputum smear-positive pulmonary or extrapulmonary TB infection. Category II belongs to patients which are defaulted, irregularly treated, or sometimes relapsed. Category III is MDR TB where the patient is resistant to rifampicin which is given orally and needs further injectables and fluoroquinolones with combination. Category IV is extensively XDR TB which is resistant to two first-line agents (isoniazid and rifampicin), to any one fluoro-quinolone, and to any one second-line drug like amikacin [3].

\section{TB ASSOCIATED WITH OTHER INFECTIONS}

Human immunodeficiency virus (HIV)

Risk of the development of TB in HIV-infected patients is around 25 times greater than normal people due to patient's compromised immunity. The HIV-infected patients develop early resistance to the first-line TB agents due to drug interactions between medicines of both diseases. About $60 \%$ of TB cases associated with HIV-infected people results in early critical conditions with death of patient.

\section{M. avium complex (MAC)}

MAC is an atypical mycobacterial infection, that is, one with nontuberculous mycobacteria which consists of two mycobacterial species M. avium and Mycobacterium intracellulare. This infection causes respiratory illness in patients, especially in immunocompromised people. It is also called as opportunistic infection, because it develops when cell-mediated immunity is markedly depressed (CD4 count drops to $<50$ cells $/ \mu \mathrm{L}$ ).

\section{CURRENT SCENARIO OF TB INFECTION}

At present, 10.0 million people around the world acquire TB disease, out of which 1 million cases occurred in infants and children. 1.6 million TB-related deaths worldwide including 0.3 million infected with HIV. Multidrug-resistant TB (MDR-TB) remains a public health crisis, the WHO estimated that there were 0.6 million new cases with resistance to rifampicin. About $82 \%$ had MDR-TB. Globally, TB incidence is declining about $2 \%$ per year, which should be accelerated to $4-5 \%$ to reduce TB risk. The summarized view of statistical data is depicted in Fig. 1.

\section{CURRENT TB THERAPY}

The current TB treatment is based on guidelines of the World Health Organization. According to clinical utility, the anti-TB drugs are divided into five groups as described below. 
Group I (First-line agents)

These drugs have high efficacy as well as low toxicity they are used routinely. The drugs are isoniazid $(\mathrm{H})$, rifampicin $(\mathrm{R})$, pyrazinamide $(\mathrm{Z})$, ethambutol (E), and streptomycin (S).

\section{Group II (Injectable drugs)}

These are various types of antibiotics which are prescribed for MDR and XDR TB. They are administered through intravenous or other parenteral routes. Commonly used drugs are kanamycin $(\mathrm{Km})$, amikacin $(\mathrm{Am})$, and capreomycin $(\mathrm{Cm})$.

\section{Group III (Fluoroquinolones)}

The most popular antibacterial of quinolone class are used in case of MDR-TB when patients develop resistance for first-line and secondline agents. The commonly used fluoroquinolones are ofloxacin (Ofx), levofloxacin (Lfx), moxifloxacin (Mfx), and ciprofloxacin (Cfx)

\section{Group IV (Second-line agents)}

These drugs have low efficacy or high toxicity or both and are used as reserve drugs. The drugs are ethionamide (Eto), prothionamide (Pto), cycloserine (Cs), trazodone (Trd), para-amino salicylic acid (PAS), rifabutin, and thiacetazone (Thz).

\section{Group V (Drugs with unclear efficacy)}

These drugs are used when the patient develops XDR-TB phase of infection. These are broad spectrum antibiotics such as broad-spectrum penicillins, sulfonamides, and macrolide antibiotics. Commonly used are amoxicillin/clavulanic acid, thiacetazone, clarithromycin, clofazemine, linezolid, and imipenem [4-8]. The common anti-TB drugs with their

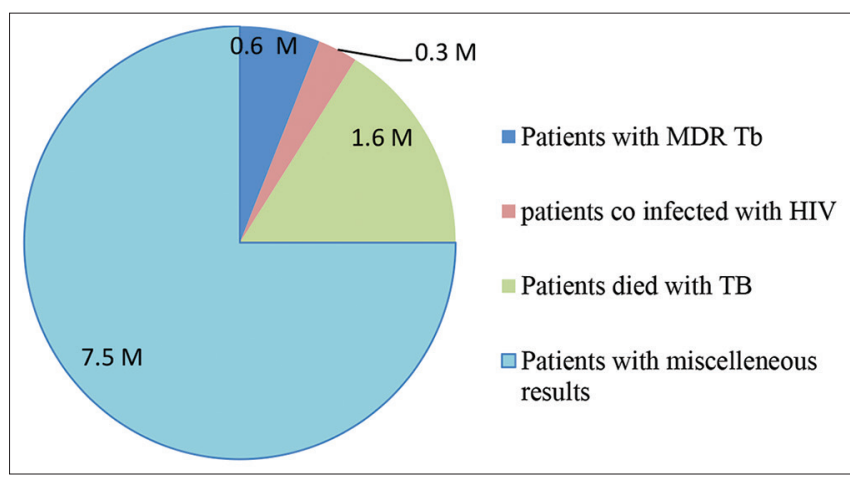

Fig. 1: Statistical evaluation of tuberculosis infection<smiles>NNC(=O)c1ccncc1</smiles><smiles>NC(=O)c1cncnc1</smiles><smiles>CCC(CO)NCCNC(CC)CO</smiles><smiles>O=C(O)c1cn(C2CC2)c2c(N3CCNCC3)c(F)ccc2c1=O</smiles><smiles>NC1CONC1=O</smiles><smiles>Nc1ccc(C(=O)O)c(O)c1</smiles>

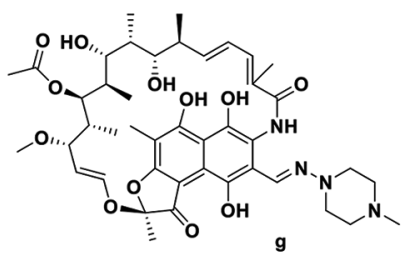

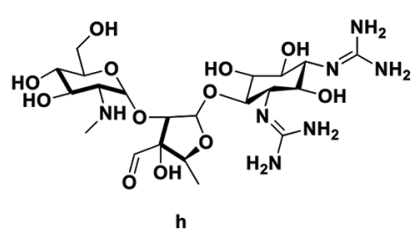

Fig. 2: Popular anti-TB drugs. (a: Isoniazid, b: Pyrazinamide, c: Ethambutol, d: Ciprofloxacin, e: D-cycloserine, f: $p$-Amino Salicylic acid, g: Ciprofloxacin, h: Streptomycin) mode of action, binding site, and category are summarized as depicted below (Fig. 2 and Table 1).

The anti-TB agents are prescribed in combination as per the guidelines given by the WHO. The Directly Observed Therapy Short-course (DOTS) program is followed for the treatment of TB. The patients are grouped according to site and severity of disease, sputum smear condition, and patient history. The DOTS therapy regimen is summarized in Table 2.

\section{TARGETS OF ANTI-TB TREATMENT}

Although the disease having wide range of drugs serving the treatment, still there is a need to develop new drug candidate as the current treatment is having two major problems one is discontinuation of therapy by patient due to longer duration of time and second is the development of resistance to maximum drug candidates by mycobacterial strains over the period. For the development of drugs, the research has new dimension of genomics which provide information about the nature of enzymes and metabolites of the pathogens, which will help to design scaffold for potential drug targets. To develop new anti-TB drug, mycobacterial cell envelope is attractive core. Mycobacteria have unique cell wall structure, which regulates major cell functions. The mycobacterial cell has been explored for enzymatic and genomic pathways which can be targeted for drug discovery in the past few years numerous gene targets have been explored for the anti-tubercular drug development across the globe. Out of which cell wall synthesis/cell envelope was the prime target for researchers. The targets are classified based on its presence in the cell wall $[9,10]$. To understand the targets, study of components of cell membrane of the mycobacteria is to be done. The mycobacterial cell wall primarily comprises arabinogalactan, peptidoglycan, and mycolic acid. Other than these components, it contains carrier proteins, carbohydrates, and lipids. The detailed structure of mycobacterial cell membrane is described in the diagram below (Fig. 3).

\section{COMPONENTS OF MYCOBACTERIAL CELL WALL}

Chiaradia et al. examined the mycobacterial cell membrane by transmission electron microscopy and biochemical analysis. The results determined composition of the mycobacterial cell wall. It contains more than 2100 proteins between plasma membrane and mycobacterial cell wall. Among these, the mannosyl transferase (PimB), galactofuranosyl transferase (GlfT2), Cytochrome p450, and ABC transporter (YjfF) were

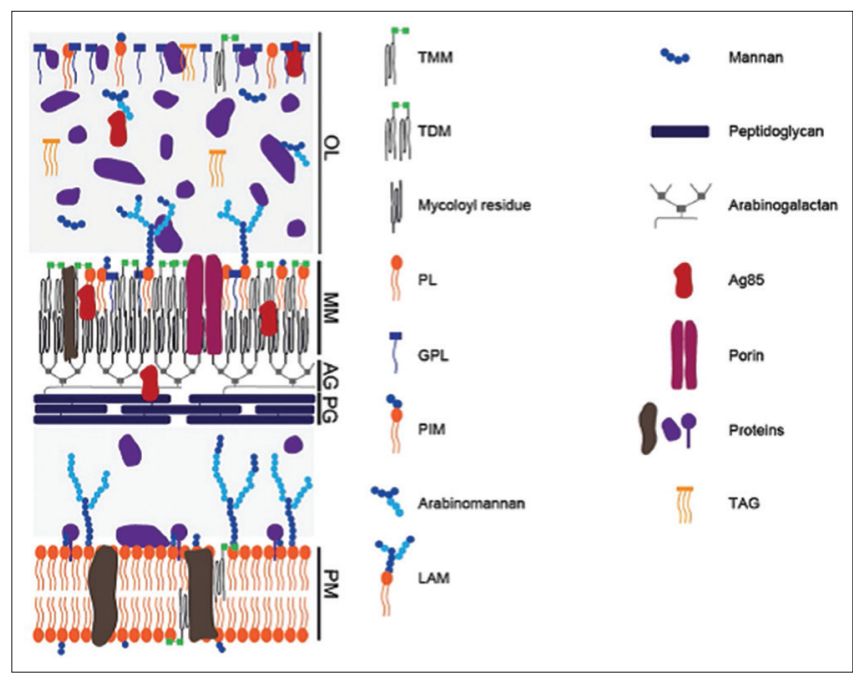

Fig. 3: Mycobacterial cell wall structure. MM: Trehalose monomycolates; PIM: Phosphatidyl-myo-inositol mannosides; GPL: Glycopeptidolipids; TDM: Trehalose dimycolates;

LAM: Lipoarabinomannans; Ag85: Antigen 85; PL: Phospholipids; TAG: Triacylglycerols 
Table 1: Popular anti-TB drugs with mode of action and mechanism of resistance

\begin{tabular}{|c|c|c|c|c|c|c|}
\hline $\begin{array}{l}\text { S. } \\
\text { No. }\end{array}$ & Drug & $\begin{array}{l}\text { Route of } \\
\text { administration }\end{array}$ & Action against & $\begin{array}{l}\text { Primary binding site } \\
\text { and mechanism of } \\
\text { action }\end{array}$ & $\begin{array}{l}\text { Specific gene and } \\
\text { mechanism of action }\end{array}$ & $\begin{array}{l}\text { Reason to } \\
\text { develop } \\
\text { mechanism }\end{array}$ \\
\hline \multicolumn{7}{|c|}{ First-line anti-TB agents } \\
\hline 1. & Isoniazid (E) & $\begin{array}{l}\text { Oral, } \\
\text { intramuscular }\end{array}$ & $\begin{array}{l}\text { Extracellular and } \\
\text { intracellular, fast } \\
\text { multiplying bacteria }\end{array}$ & $\begin{array}{l}\text { KatG, inhibition of cell } \\
\text { wall synthesis (mycolic } \\
\text { acid) }\end{array}$ & $\begin{array}{l}\text { Inhibition of } \operatorname{Inh} A \text { and } K a s A \\
\text { by binding with NAD, as } \\
\text { well inhibits mycobacterial } \\
\text { DHFRase by binding with } \\
\text { NADP }\end{array}$ & $\begin{array}{l}\text { Mutation in } \\
\text { KatG, } \operatorname{Inh} A \text {, and } \\
\text { KasA }\end{array}$ \\
\hline 2. & Rifampicin (R) & Oral & $\begin{array}{l}\text { Extracellular and } \\
\text { intracellular, slowly } \\
\text { OR intermediately } \\
\text { dividing once }\end{array}$ & $\begin{array}{l}\text { RpoB, interfere with } \\
\text { mycobacterial DNA } \\
\text { function }\end{array}$ & $\begin{array}{l}\text { Interruption of RNA } \\
\text { synthesis by binding to } \\
\beta \text { - submit of mycobacterial } \\
\text { DNA-dependent RNA } \\
\text { polymerase }\end{array}$ & $\begin{array}{l}\text { Mutation in } \\
R p o B\end{array}$ \\
\hline 3. & Pyrazinamide (Z) & Oral & $\begin{array}{l}\text { Intracellular and at } \\
\text { inflamed sites }\end{array}$ & $\begin{array}{l}p n c A \text {, inhibition of cell } \\
\text { wall synthesis (mycolic } \\
\text { acid) }\end{array}$ & $\begin{array}{l}\text { Get converted to pyrazinoic } \\
\text { acid and accumulates in } \\
\text { acidic medium, results in } \\
\text { inhibition of mycolic acid } \\
\text { synthesis }\end{array}$ & Mutation in $p n c A$ \\
\hline 4. & Ethambutol (E) & Oral & $\begin{array}{l}\text { Intracellular and fast } \\
\text { multiplying bacteria }\end{array}$ & $\begin{array}{l}E m b A B \text {, inhibition of cell } \\
\text { wall synthesis (mycolic } \\
\text { acid) }\end{array}$ & $\begin{array}{l}\text { Inhibition of arabinosyl } \\
\text { transferases, involves in } \\
\text { arabinogalactan synthesis } \\
\text { thereby inhibit mycolic acid } \\
\text { synthesis }\end{array}$ & $\begin{array}{l}\text { Mutation in } \\
e m b B\end{array}$ \\
\hline 5. & Streptomycin (S) & Intramuscular & Extracellular & $\begin{array}{l}\text { 30S ribosome, interfere } \\
\text { with protein synthesis }\end{array}$ & $\begin{array}{l}\text { Inhibition of protein } \\
\text { synthesis prevent } \\
\text { polysome formation, } \\
\text { promotes disaggregation to } \\
\text { monosomes }\end{array}$ & $\begin{array}{l}\text { Decreasing } \\
\text { affinity of } \\
\text { binding site of } \\
\text { ribosomes }\end{array}$ \\
\hline \multicolumn{7}{|c|}{ Second-line anti-TB agents } \\
\hline 6. & $\begin{array}{l}\text { Fluoroquinolones } \\
\text { (FQs) }\end{array}$ & $\begin{array}{l}\text { Oral, } \\
\text { intravenous }\end{array}$ & $\begin{array}{l}\text { Intracellular and } \\
\text { extracellular }\end{array}$ & $\begin{array}{l}\text { DNA gyrase A subunit, } \\
\text { Inhibition of bacterial } \\
\text { DNA gyrase }\end{array}$ & $\begin{array}{l}\text { Binds with A subunit } \\
\text { and interfere with strand } \\
\text { breakdown and realizing } \\
\text { function }\end{array}$ & $\begin{array}{l}\text { Chromosomal } \\
\text { mutation- } \\
\text { producing DNA } \\
\text { gyrase enzyme }\end{array}$ \\
\hline 7. & $\begin{array}{l}\text { Ethionamide (Eto), } \\
\text { Prothionamide (Pto) }\end{array}$ & Oral & $\begin{array}{l}\text { Intracellular and } \\
\text { Extracellular }\end{array}$ & $\begin{array}{l}\text { eth } A \text {, inhibition of cell } \\
\text { wall synthesis (mycolic } \\
\text { acid) }\end{array}$ & $\begin{array}{l}\text { Binds NAD + to form adduct } \\
\text { which inhibits InhA in the } \\
\text { same way as isoniazid. The } \\
\text { mechanism of action is } \\
\text { disruption of mycolic acid }\end{array}$ & $\begin{array}{l}\text { Mutation in } \\
\text { gene producing } \\
\text { mono-oxygenase } \\
\text { enzyme }\end{array}$ \\
\hline 8. & Cycloserine (Cs) & Oral & $\begin{array}{l}\text { Intracellular and } \\
\text { extracellular }\end{array}$ & $\begin{array}{l}\text { Alanine racemase, } \\
\text { inhibition of cell } \\
\text { wall biosynthesis } \\
\text { (Peptidoglycan) }\end{array}$ & $\begin{array}{l}\text { Inhibition of bacterial } \\
\text { cell wall synthesis by } \\
\text { inactivating the enzymes } \\
\text { which racemize L-alanine } \\
\text { and } 2 \text { D- alanine residues }\end{array}$ & $\begin{array}{l}\text { Mutation } \\
\text { in alanine } \\
\text { racemase }\end{array}$ \\
\hline 9. & $\begin{array}{l}\text { Para-amino salicylic } \\
\text { acid (PAS) }\end{array}$ & Oral & $\begin{array}{l}\text { Extracellular and } \\
\text { intracellular, fast } \\
\text { multiplying bacteria }\end{array}$ & $\begin{array}{l}\text { Inhibition of folic acid } \\
\text { synthesis }\end{array}$ & $\begin{array}{l}\text { Incorporated into the folate } \\
\text { pathway DHPS and DHFS }\end{array}$ & \\
\hline \multicolumn{7}{|c|}{ Injectable agents } \\
\hline 10. & $\begin{array}{l}\text { Kanamycin }(\mathrm{Km}), \\
\operatorname{amikacin}(\mathrm{Am})\end{array}$ & Intravenous & $\begin{array}{l}\text { Intracellular, } \\
\text { macrophages, and } \\
\text { extracellular }\end{array}$ & $\begin{array}{l}\text { 30S-50s ribosome, } \\
\text { interfere with protein } \\
\text { synthesis }\end{array}$ & $\begin{array}{l}\text { Inhibition of protein } \\
\text { synthesis prevent } \\
\text { polysome formation, } \\
\text { promotes disaggregation to } \\
\text { monosomes }\end{array}$ & $\begin{array}{l}\text { Decreasing } \\
\text { affinity of } \\
\text { binding site of } \\
\text { ribosomes }\end{array}$ \\
\hline
\end{tabular}

most abundant in the plasma membrane. Plasma membrane also contains lipoglycans, phospholipids including phosphatidylinositol mannosides, and other glycolipids [11]. Antigen 85 complex proteins, porins, putative transporters, and mammalian cell entry protein family were mostly found in mycobacterial cell wall fraction that contains mycolic acid esterifying arabinogalactan constituting the inner leaflet of mycomembrane, along with glycolipids, phospholipids, lipoglycans, and proteins [12].

The cell wall of mycobacteria contains outermost layer (OL) which constitutes proteins with carbohydrate and negligible amount of lipids. After the OL layer of mycolic acid, mycomembrane (MM), arabinogalactan (AG), and peptidoglycan (PG) are present, respectively. The inner leaflet of the MM is made of very long-chain fatty acids (mycolic acids) esterifying (AG), covalently attached to (PG). The outer leaflet of the MM is presumably composed of lipids extractable with organic solvents, which includes phospholipids, trehalose mycolates, glycopeptidolipids, and lipoglycans. A periplasmic space separates the cell wall from the conventional lipid bilayer of plasma membrane (PM) of phospholipids and proteins. The cell envelop has different components regulated by various enzymes. The enzymes are primary targets for cell wall inhibition. Mycolic acid metabolism is considered as upcoming target related to mycolic acid [13]. 
Table 2: Category wise treatment regimens for TB

\begin{tabular}{|c|c|c|c|c|}
\hline Category & Intensive phase & Continuous phase & $\begin{array}{l}\text { Duration } \\
\text { (months) }\end{array}$ & Comment \\
\hline \multirow{3}{*}{ I New patient } & $2^{\$}$ HRZE daily & $4^{\$} \mathrm{HR}$ daily & $6^{\$}$ & Optimal \\
\hline & 2 HRZE daily & $4^{\$} \mathrm{HR}$ thrice weekly & 6 & Acceptable if DOT ensured \\
\hline & 2 HRZE thrice weekly & $4^{\$} \mathrm{HR}$ thrice weekly & 6 & Acceptable if DOT ensured \\
\hline \multirow{3}{*}{$\begin{array}{l}\text { II Previously treated } \\
\text { patients pending } \\
\text { DST result }\end{array}$} & 2 HRZES daily + 1 HRZE daily & 5 HRE daily & 8 & $\begin{array}{l}\text { For patient with low/medium risk of } \\
\text { MDR-TB }\end{array}$ \\
\hline & & & & (failure, default) \\
\hline & Empirical $^{E}$ (standardized) MDR-regimen & $\begin{array}{l}\text { Empirical } \\
\text { (standardized) MDR- } \\
\text { regimen }\end{array}$ & $\begin{array}{l}18-24 \text { Or till DST } \\
\text { results }\end{array}$ & $\begin{array}{l}\text { For patients with high risk of MDR-TB } \\
\text { (failure, } 2^{\text {nd }} \text { default, contact of MDR- } \\
\text { TB) }\end{array}$ \\
\hline III MDR-TB & $\begin{array}{l}\text { 6-9 Any } 4 \text { of Km, Ofx/Lfx, Eto, Cs, Z, E, } \\
\text { PAS + Pyridoxine } 100 \text { mg/day }\end{array}$ & $\begin{array}{l}18 \text { Any } 4 \text { of Ofx/ } \\
\text { Lfx, Eto, Cs, E, } \\
\text { PAS + Pyridoxine } \\
100 \mathrm{mg} / \text { day }\end{array}$ & $24-27$ & $\begin{array}{l}\text { For patients with failure to } 1^{\text {st }} \text { line and } \\
2^{\text {nd }} \text { line treatment }\end{array}$ \\
\hline IV XDR-TB & \multicolumn{4}{|c|}{ Group V drugs are prescribed according to the severity of infection for unpredicted period of time. } \\
\hline
\end{tabular}

DST: Drug sensitivity testing; DOT: Directly observed therapy; \$- The numerals indicate duration of phase, $€$ - Empirical (standardization) MDR regimen is country depending on local data and situation.

\section{Peptidoglycan biosynthesis}

Peptidoglycan is the essential cell wall component of mycobacterial cell wall which gives rigidity to cell. Peptidoglycan consists of N-Acetyl Glucosamine (NAG), N-Glycolyl muramic acid (NAM), and alanine (Al). The peptidoglycan biosynthesis is targeted for anti-TB drug development from decades but still any drug candidate other than D-clycoserine has not shown promising effect, D-cycloserine inhibits peptidoglycan biosynthesis by inhibiting essential enzymes alanine racemase (Alr) and D-Ala-D-Ala ligase. It was predicted that bacitracin antibiotic also targets peptidoglycan biosynthesis but exact mechanism is not known. Another target in peptidoglycan synthesis is glutamate racemase for which $\beta$-chloro-D-alanine and its derivatives are under study, the exact mechanism is not identified but the enzyme is considered as potential target. The peptidoglycan biosynthesis can be inhibited by alanine like small molecules which can act as competitive inhibitor of alanine inhibiting attachment of alanine to NAG and NAM to form peptidoglycan [14-18].

\section{Arabinogalactan biosynthesis}

The arabinogalactan layer is present just next to the peptidoglycan layer. It contains sugars like rhamnose, galactose, phospholipids, and carrier proteins. The next important target in the mycobacterial cell wall is arabinogalactan synthesis. Ethambutol is the one of the extensively used anti-TB drugs which act through inhibition of arabinogalactan synthesis through inhibition of arabinosyltransferase enzyme.

Uridine diphosphate-galactopyranose (UDP-galactopyranose) is also identified as important enzyme in this pathway which involves in attachment of galactose in the arabinogalactan. Recent studies reported that the biosynthesis of the cell wall galactan of mycobacteria through Rv3808c protein can be inhibited through galactosyl transferase enzymes. Decaprenyl phosphorylase-2-epimerases are challenging target in the mycobacterial synthesis because targeting this enzyme has many challenges due to its oxidoreductive property responsible for degeneration of chemical structure of drug. A prodrug approach toward the drug development can be considered as novel way to target the enzyme, benzothiazinone which inhibits the enzyme and is under clinical investigation. From the description of enzymes, one can predict small cyclic molecules with structural similarity to galactose with hetero-atoms as potent candidates to target the pathway [19-21].

\section{Mycolic acid biosynthesis and metabolism}

Mycolic acid is unique feature of mycobacteria it is fatty acid containing carbon chain of 70 carbons. It makes the mycobacteria more resistant to chemical damage and dehydration. It also helps mycobacteria to grow inside the macrophages by effectively hiding from host immune system.
There are four types of enzymes related to mycolic acid:

1. Fatty acid synthesis I (FAS I): Ketoacyl-ACP synthases, Catalaseperoxidase

2. Fatty acid synthesis II (FAS II): ENR enoyl acyl carrier protein reductase, EthA gene

3. Fatty acid synthesis condensing enzymes: polyketide synthase (Pks13) and fatty acid desaturase (FAD13/FAD32)

4. Mycolic acid metabolism: Mycobacterial membrane protein large (mmpL), mycobacterial membrane protein small (mmpS).

\section{Fatty acid synthesis I pathway (FAS I)}

The pathway includes synthesis of $\mathrm{C}_{26}$ straight chain fatty acids, which involves enzymes such as Ketoacyl-ACP synthases (CasA) and Catalaseperoxidase (KatG). The enzymes are inhibited by popular drugs such as isoniazid, pyrazinamide, and ethionamide. The drugs are susceptible to resistance due to mutations in genes regulating the enzyme. The ketoacyl-ACP synthases enzyme is indirectly involved in mechanism of many drugs but direct target for the enzyme is under study. The KatG is involved in activation of isoniazid into isoform to the anion of nicotinic acid, which further inhibits the cell all synthesis by inhibiting FAS II pathway competitively. FAS I pathway can be inhibited by chemical moieties such as thiazolidine linezolid and heterocyclic five and sixmembered derivatives [22,23].

\section{Fatty acid synthesis II pathway (FAS II)}

The pathway further involves in chain elongation and addition of functional groups to the chain. It involves enzymes such as enoyl acyl carrier protein reductase (InhA) and EthA gene. The well-known drug isoniazid inhibits (InhA) enzymes after activation by KatG. EthA gene is another target on the FAS II pathway which is inhibited by ethionamide. To inhibit FAS II pathway, there are many chemically and biologically important scaffolds such as epigallocatechin gallate, luteolin, cinnamic acid derivatives, quinones, thiocarbamides, and diphenyl ether $[24,25]$.

\section{Fatty acid synthesis condensing pathway}

The pathways involve condensation and attachment of mycolic acid to arabinogalactan layer. The enzymes involved in pathway are polyketide synthase (Pks13) and fatty acid desaturase (Fad13/Fad32). The pathways are not having any current potential anti-TB targets. However, there are numerous drugs and enzyme pathways such as acyl-adenylate monophosphate ligase (acyl-AMP ligase), FadD32, acyl-coenzyme A $(\mathrm{CoA})$ carboxylase. Benzofuran, thiophene, and coumarin derivative inhibit the fatty acid synthesis condensing pathway [26].

\section{Mycolic acid metabolism pathway}

The mycolic acid metabolism is indirectly involved in mechanism of many antitubercular drugs and has important function of the drug influx 
Table 3: Summary of enzyme targets in mycobacterial cell wall synthesis

\begin{tabular}{|c|c|c|c|c|c|c|c|}
\hline $\begin{array}{l}\text { S. } \\
\text { No. }\end{array}$ & $\begin{array}{l}\text { Target (Gene/ } \\
\text { Enzyme) }\end{array}$ & Specific target & $\begin{array}{l}\text { Mechanism of target } \\
\text { enzyme }\end{array}$ & $\begin{array}{l}\text { Drug target } \\
\text { synthesized/ } \\
\text { in use }\end{array}$ & $\begin{array}{l}\text { Mechanism of } \\
\text { drug }\end{array}$ & $\begin{array}{l}\text { Novel target } \\
\text { identified drug/ } \\
\text { enzyme }\end{array}$ & $\begin{array}{l}\text { Scaffolds under } \\
\text { research/clinical } \\
\text { trials }\end{array}$ \\
\hline \multirow[t]{2}{*}{1.} & \multirow[t]{2}{*}{$\begin{array}{l}\text { Peptidoglycan } \\
\text { biosynthesis }\end{array}$} & $\begin{array}{l}\text { Alanine } \\
\text { racemase (Alr), } \\
\text { D-Ala-D-Ala } \\
\text { ligase }\end{array}$ & $\begin{array}{l}\text { Catalysis of first } 2 \\
\text { steps of Peptidoglycan } \\
\text { biosynthesis }\end{array}$ & $\begin{array}{l}\text { D-cycloserine, } \\
\text { bacitracin, }\end{array}$ & $\begin{array}{l}\text { Inhibition of } \\
\text { bacterial cell } \\
\text { wall synthesis } \\
\text { by inactivating } \\
\text { the enzymes } \\
\text { which racemize } \\
\text { L-alanine and } \\
2 \text { D- alanine } \\
\text { residues }\end{array}$ & $\begin{array}{l}\text { Alanine like small } \\
\text { molecules }\end{array}$ & -- \\
\hline & & $\begin{array}{l}\text { Glutamate } \\
\text { racemase }\end{array}$ & 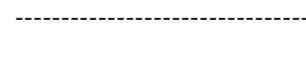 & ------UNDER & 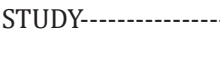 & - & $\begin{array}{l}\beta \text {-Chloro-D- } \\
\text { Alanine }\end{array}$ \\
\hline \multirow[t]{3}{*}{$\begin{array}{l}2 . \\
1 .\end{array}$} & \multirow[t]{3}{*}{$\begin{array}{l}\text { ARABINOGALACTAN } \\
\text { BIOSYNTHESIS }\end{array}$} & $\begin{array}{l}\text { Arabinosyl } \\
\text { transferases } \\
(\text { EmbA, EmbB, } \\
\text { EmbC) }\end{array}$ & $\begin{array}{l}\text { Formation of } \\
\text { the terminal } \\
\text { hexaarabinofuranoside } \\
\text { portion of } \\
\text { arabinogalactan, } \\
\text { where mycolic acid get } \\
\text { attached }\end{array}$ & Ethambutol & $\begin{array}{l}\text { Inhibition of } \\
\text { arabinosyl } \\
\text { transferases, } \\
\text { involves in } \\
\text { arabinogalactan } \\
\text { synthesis, } \\
\text { thereby inhibit } \\
\text { mycolic acid } \\
\text { synthesis }\end{array}$ & $\begin{array}{l}\text { UDP- } \\
\text { galactopyranose }\end{array}$ & \\
\hline & & $\begin{array}{l}\text { Galactosyl } \\
\text { transferases } \\
\text { (Galf) }\end{array}$ & $\begin{array}{l}\text { Biosynthesis of the } \\
\text { cell wall galactan of } \\
\text { mycobacteria through } \\
\text { Rv3808c protein }\end{array}$ & 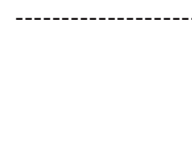 & -------UNDER STU & 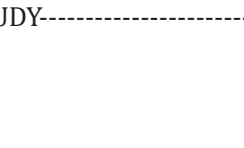 & - n--- \\
\hline & & $\begin{array}{l}\text { Decaprenyl } \\
\text { phosphorylase- } \\
\text { 2-epimerase } \\
\text { (DprE1/DprE2) }\end{array}$ & $\begin{array}{l}\text { Arabinofuranose donor } \\
\text { in biogenesis of AG and } \\
\text { LAM }\end{array}$ & --- & $\begin{array}{l}\text { Inhibition of } \\
\text { (DPA) formation }\end{array}$ & $\begin{array}{l}\text { Dinitrobenzamide } \\
\text { derivatives }\end{array}$ & Benzothiazinone \\
\hline 3. & $\begin{array}{l}\text { Mycolic Acid } \\
\text { Biosynthesis FAS-I } \\
\text { pathway }\end{array}$ & $\begin{array}{l}\text { Catalase- } \\
\text { peroxidase } \\
\text { (KatG) }\end{array}$ & $\begin{array}{l}\text { Activation of } \mathrm{NAD}^{+} \\
\text {enzyme by electron } \\
\text { donation }\end{array}$ & Isoniazid & $\begin{array}{l}\text { Inhibition of } \\
\text { InhA and KasA } \\
\text { by binding } \\
\text { with NAD, as } \\
\text { well inhibits } \\
\text { mycobacterial } \\
\text { DHFRase by } \\
\text { binding with } \\
\text { NADP }\end{array}$ & $\begin{array}{l}\text { Linezolid, } \\
\text { thiazolidine } \\
\text { derivatives }\end{array}$ & --- \\
\hline \multirow[t]{2}{*}{4.} & \multirow[t]{2}{*}{$\begin{array}{l}\text { Mycolic acid } \\
\text { biosynthesis FAS-II } \\
\text { pathway }\end{array}$} & $\begin{array}{l}\text { ENR enoyl acyl } \\
\text { carrier protein } \\
\text { reductase } \\
\text { (InhA) }\end{array}$ & $\begin{array}{l}\text { Catalysis of extension } \\
\text { of fatty acid chain up } \\
\text { to C56 }\end{array}$ & $\begin{array}{l}\text { Isoniazid } \\
\text { (ENR subunit } \\
\text { of InhA) }\end{array}$ & $\begin{array}{l}\text { Inhibition of } \\
\text { InhA and KasA } \\
\text { by binding } \\
\text { with NAD, as } \\
\text { well inhibits } \\
\text { mycobacterial } \\
\text { DHFRase by } \\
\text { binding with } \\
\text { NADP }\end{array}$ & $\begin{array}{l}\text { FabH, MabA, } \\
\text { Epigallocatechin } \\
\text { gallate luteolin } \\
\text { cinnamic } \\
\text { derivatives } \\
\text { quinones diphenyl } \\
\text { ether }\end{array}$ & --- \\
\hline & & $\begin{array}{l}\text { Flavin adenine } \\
\text { dinucleotide } \\
\text { (FAD)- } \\
\text { containing } \\
\text { Baeyer-Villiger } \\
\text { monooxygenase } \\
\text { (EthA) }\end{array}$ & $\begin{array}{l}\text { Catalysis of extension } \\
\text { of Fatty Acid Chain up } \\
\text { to C } 56\end{array}$ & Ethionamide & $\begin{array}{l}\text { Inhibition of } \\
\text { InhA }\end{array}$ & $\begin{array}{l}\text { Thiocarbamide } \\
\text { derivatives }\end{array}$ & ---- \\
\hline
\end{tabular}


Table 3: (Continued)

\begin{tabular}{|c|c|c|c|c|c|c|c|}
\hline $\begin{array}{l}\text { S. } \\
\text { No. }\end{array}$ & $\begin{array}{l}\text { Target (Gene/ } \\
\text { Enzyme) }\end{array}$ & Specific target & $\begin{array}{l}\text { Mechanism of target } \\
\text { enzyme }\end{array}$ & $\begin{array}{l}\text { Drug target } \\
\text { synthesized/ } \\
\text { in use }\end{array}$ & $\begin{array}{l}\text { Mechanism of } \\
\text { drug }\end{array}$ & $\begin{array}{l}\text { Novel target } \\
\text { identified drug/ } \\
\text { enzyme }\end{array}$ & $\begin{array}{l}\text { Scaffolds under } \\
\text { research/clinical } \\
\text { trials }\end{array}$ \\
\hline \multirow[t]{2}{*}{5.} & \multirow[t]{2}{*}{$\begin{array}{l}\text { Mycolic acid } \\
\text { biosynthesis FAS } \\
\text { condensing enzyme }\end{array}$} & $\begin{array}{l}\text { polyketide } \\
\text { synthase } \\
\text { (Pks13) }\end{array}$ & $\begin{array}{l}\text { Catalysis of the } \\
\text { final condensation } \\
\text { step in mycolic acid } \\
\text { biosynthesis }\end{array}$ & \multicolumn{2}{|c|}{---------UNDER STUDY--------- } & $\begin{array}{l}\text { acyl-AMP ligase, } \\
\text { Benzofuran; } \\
\text { thiophene } \\
\text { Coumarins }\end{array}$ & --- \\
\hline & & $\begin{array}{l}\text { Flavin adenine } \\
\text { dinucleotide } \\
\text { (FadD13/ } \\
\text { FAD32) }\end{array}$ & $\begin{array}{l}\text { Part of fatty acid acyl } \\
\text { ligase (FAAL) which } \\
\text { adenylate Fatty acid } \\
\text { long chain which is } \\
\text { transferred to pks13 }\end{array}$ & ----------UNDE & R STUDY------- & $\begin{array}{l}\text { Coumarin } \\
\text { derivatives }\end{array}$ & $\begin{array}{l}\text { Fatty acid } \\
\text { derivatives }\end{array}$ \\
\hline 6. & $\begin{array}{l}\text { Mycolic } \\
\text { metabolism }\end{array}$ & $\begin{array}{l}\text { MmpL } \\
\text { MmpS }\end{array}$ & $\begin{array}{l}\text { Mediate transport } \\
\text { of important cell } \\
\text { wall lipids across } \\
\text { the mycobacterial } \\
\text { membrane. }\end{array}$ & $\begin{array}{l}\text { Indirect } \\
\text { involvement } \\
\text { in transport } \\
\text { of drug } \\
\text { molecules }\end{array}$ & ---- & --- & SQ109 \\
\hline
\end{tabular}

in mycobacteria. The acid associated pathways can be explored through different scaffolds such as cinnamic acid, thiazolidine, rhodanine scaffolds, and many other natural products [27-37]. Summary of enzyme targets is depicted in Table 3.

\section{ANTI-TB SCAFFOLDS IN PIPELINE}

The era of anti-TB drug development is rapidly changing from phenotypic to genotypic research. Till date, numerous scaffolds are explored for this purpose. The scaffolds screened are ranging from NCE's obtained from natural sources, biological extracts, and enzymes from genetically modified microorganisms and from synthetic sources. In the past 10 years, various scaffolds from synthetic source such as $\beta$-chloro-D-alanine, ethers, dinitrobenzamide (benzothiazinone), linezolid, thiocarbamides, cinnamic acid, benzofuran, and quinazolinones derivatives are used. Few natural products such as epigallocatechin, quinines, and coumarins are also explored for the development of new drug.

\section{CONCLUSION}

Today, it is very important to develop new anti-TB drugs. With the help of enzymatic and genetic pathways, we can achieve target-based drug development which will be helpful to overcome the problems associated with existing anti-TB therapy. The unique structure of mycobacterial cell wall makes it ideal for target-based drug development. The architecture of the mycobacterial cell wall is complex and represents a substantial permeability barrier that is made up of a wide variety of compounds including mycolic acids, free lipids, polysaccharides, glycolipids, and lipoarabinomannan. Many of these components are genera or species specific. Most of the existing anti-TB drug candidates targets cell wall to inhibit bacterial growth. Nevertheless, none of the known cell wall synthesis inhibitors are endowed with rapidly acting sterilizing activity, hence, these drugs are urgently needed in TB control programs. All apparently require actively replicating bacteria for efficacy. A problematic issue one addresses latent TB, a condition in which mycobacteria are not actively dividing or synthesizing cell wall component which is apparently prevalent in about one-third of the global population. At present, the anti-TB drug development should be focused on potent drug candidates who can withstand to MDR TB. The novel drug development includes targeting unexplored cell wall components for drug development, shortening duration of existing drug therapy, development of potent anti-TB drugs, and repurposing of old drugs.

\section{ACKNOWLEDGMENT}

The authors are thankful to Government of India DST-SERB for providing financial assistance and principal of Poona College of Pharmacy, Pune, for encouragement and support in carrying out the work.

\section{CONFLICTS OF INTEREST}

The authors declare that there are no conflicts of interest regarding the publication of this research article.

\section{REFERENCES}

1. World Health Organisation. Global TUBERCULOSIS Report. Geneva, Switzerland, France: World Health Organisation; 2019.

2. Ahmad S, Mokaddas E. Current status and future trends in the diagnosis and treatment of drug-susceptible and multidrug-resistant Tuberculosis. J Infect Public Health 2014;7:75-91.

3. Palomino JC, Martin A. Drug resistance mechanisms in Mycobacterium tuberculosis. Antibiotics 2014;3:317-40.

4. Tripathi KD. Antitubercular drugs. In: Essentials of Medical Pharmacology. $7^{\text {th }}$ ed. India: Jaypee Brother's Medical Publishers $(\mathrm{P})$ Ltd.; 2013. p. 765-79.

5. Gentry CA. Atypical Mycobacteria. In: Pharmacotherapy Selfassessment Program. $5^{\text {th }}$ ed. United States: Learning Objectives; 2006. p. $99-126$.

6. Foye WO, Lemke TL, Williams DA. Antimycobacterial agents. In: Foye's Principles of Medicinal Chemistry. $6^{\text {th }}$ ed. United States: Lippincott Williams and Wilkins; 2008. p. 1128-38.

7. Eduardo PD, Palomino JC. Molecular basis and mechanisms of drug resistance in Mycobacterium tuberculosis: Classical and new drugs. J Antimicrob Chemother 2011;66:1417-30.

8. Directorate General of Health Services-Central TB Division. Revised National TB control programme (India), India TB Report-2019, Annual Study Report. India: Directorate General of Health Services-Central TB Division; 2019.

9. Kaneko T, Cooper C, Mdluli K. Challenges and opportunities in developing novel drugs for TB. Future Med Chem 2011;3:1373-400.

10. Chiaradia L, Lefebvre C, Parra J, Marcoux J, Burlet-Schiltz O, Etienne $\mathrm{G}$, et al. Dissecting the mycobacterial cell envelope and defining the composition of the native mycomembrane. Sci Rep 2017;7:1-12.

11. Crick PJ. The cell-wall core of Mycobacterium tuberculosis in the context of drug discovery. Curr Top Med Chem 2007;7:475-88.

12. Singh G, Kumar A, Maan P, Kaur J. Cell wall associated factors of Mycobacterium tuberculosis as major virulence determinants: Current perspectives in drugs discovery and design. Curr Drug Targets 2017;18:1904-18.

13. Chatterjee D. The Mycobacterial cell wall: Structure, biosynthesis and sites of drug action. Curr Opin Chem Biol 1997;1:579-88.

14. Mdluli K, Spigelman M. Novel targets for Tuberculosis drug discovery. Curr Opin Pharmacol 2006;6:459-67.

15. LeMagueres P, Im H, Ebalunode J, Strych U, Benedik MJ, Briggs JM, et $a l$. The $1.9 \AA$ crystal structure of alanine racemase from Mycobacterium tuberculosis contains a conserved entryway into the active site. Biochemistry 2005;44:1471-81.

16. Halouska S, Chacon O, Fenton RJ, Zinniel DK, Barletta RG, Powers R. Use of NMR metabolomics to analyze the targets of d-cycloserine in Mycobacteria: Role of d-alanine racemase. J Proteome Res 2007;6:4608-14.

17. Prosser GA, Rodenburg A, Khoury H, de Chiara C, Howell S, 
Snijders AP, et al. Glutamate racemase is the primary target of $\beta$-chloro-D-alanine in Mycobacterium tuberculosis. Antimicrob Agents Chemother 2016;60:6091-9.

18. David S. Synergic activity of d-cycloserine and $\beta$-chloro-d-alanine against Mycobacterium tuberculosis. J Antimicrob Chemother 2001;47:203-6.

19. Rombouts Y, Brust B, Ojha AK, Maes E, Coddeville B, Elass-Rochard E, et al. Exposure of Mycobacteria to cell wall-inhibitory drugs decreases production of arabinoglycerolipid related to mycolyl-arabinogalactanpeptidoglycan metabolism. J Biol Chem 2012;287:11060-9.

20. Martina B, Petronela D, Patrick J, Gladys C, Completo, Natisha L, et al Galactosyl transferases in mycobacterial cell wall synthesis. J Bacteriol 2008;190:1141-45.

21. Giovanna R, Maria RP, Laurent RC, Giulia M, Andrea M, Claudia B. The DprE1 enzyme, one of the most vulnerable targets of Mycobacterium tuberculosis. Appl Microbiol Biotechnol 2013;97:8841-48.

22. Apoorva B, Virginie M, Gurdyal SB, William RJ, Laurent K. Micro review: The Mycobacterium tuberculosis FAS-II condensing enzymes: Their role in mycolic acid biosynthesis, acid-fastness, pathogenesis and in future drug development. Mol Micro 2007;64:1442-54.

23. Christine EC, Adrienne CD, Katalin FM, Saida PS, Reza AG. Isoniazidresistance conferring mutations in Mycobacterium tuberculosis KatG: Catalase, peroxidase, and INH-NADH adduct formation activities. Protein Sci 2010;19:458-74

24. Shrinivas DJ, Sheshagiri RD, Uttam AM, Tejraj MA, Venkatrao HK, Andanappa KG. Enoyl ACP reductase as effective target for the synthesized novel antitubercular drugs: A-state-of-the-art. Mini Rev Med Chem 2014;14:678-93.

25. Evans JC, Mizrahi V. Priming the Tuberculosis drug pipeline: New antimycobacterial targets and agents. Curr Opin Microbiol 2018;45:39-46.

26. Sarah AS, Tomohiko K, Noriaki I, Motohisa S, Anne EC, Edward K, et al. Diarylcoumarins inhibit mycolic acid biosynthesis and kill Mycobacterium tuberculosis by targeting FadD32. Proc Natl Acad Sci
U S A 2013;110:11565-70.

27. Varela C, Rittmann D, Singh A, Krumbach K, Bhatt K, Eggeling L, et al. MmpL genes are associated with mycolic acid metabolism in Mycobacteria and Corynebacteria. Chem Biol 2012;19:498-506.

28. Eoh H, Brennan PJ, Crick DC. The Mycobacterium tuberculosis MEP (2C-methyl-d-erythritol 4-phosphate) pathway as a new drug target. Tuberculosis 2009;89:1-11.

29. Boshoff HI, Barry CE. Is the Mycobacterial cell wall a hopeless drug target for latent Tuberculosis? Drug Discov Today Dis Mech 2006;3:237-45.

30. Marrakchi H, Lanéelle G, Quemard A. InhA, a target of the antituberculous drug isoniazid, is involved in a Mycobacterial fatty acid elongation system, FAS-II. Microbiology 2000;146:289-96.

31. Janin YL. Antituberculosis drugs: Ten years of research. Bioorg Med Chem 2007;15:2479-513.

32. Palomino J, Ramos D, da Silva P. New anti-Tuberculosis drugs: Strategies, sources and new molecules. Curr Med Chem 2009;16:1898-904.

33. Paulo F M O, Brigitte G, Alain C, Christiane A B, Jan M, Jana K, et al. Mechanochemical synthesis and biological evaluation of novel isoniazid derivatives with potent antitubercular activity. Molecules 2017:22:1-27.

34. Tahlan K, Wilson R, Kastrinsky DB, Nair V, Fischer E, Barnes SW, et al. Tuberculosis SQ109 targets mmpL3, a membrane transporter of trehalose monomycolate involved in mycolic acid donation to the cell wall core of Mycobacterium tuberculosis. Antimicrob Agents Chemother 2012;56:1797-809.

35. North EJ, Jackson M, Lee RE. New approaches to target the mycolic acid biosynthesis pathway for the development of Tuberculosis therapeutics. Curr Pharm Des 2014;20:4357-78.

36. Engohang J. Antimycobacterial drugs currently in Phase II clinical trials and preclinical phase for Tuberculosis treatment. Expert Opin Investig Drugs 2012;21:1789-800.

37. Islam M, Hameed H, Mugweru J, Chhotaray C, Wang C, Tan Y, et al. Drug resistance mechanisms and novel drug targets for Tuberculosis therapy. J Genet Genomics 2017;44:21-37. 